\title{
Small Intestinal Gastrointestinal Stromal Tumor
}

National Cancer Institute

\section{Source}

National Cancer Institute. Small Intestinal Gastrointestinal Stromal Tumor. NCI

Thesaurus. Code C5811.

A gastrointestinal stromal tumor that arises from the small intestine. It usually affects adults over fifty years of age. The majority of cases have spindle cell morphology. The prognosis depends on the tumor size and the mitotic activity. 